Jurnal Kesehatan 14 (1) 2021, 1-10

\title{
Hambatan-Hambatan Implementasi Perawatan Paliatif di Indonesia: Systematic Review
}

\author{
${ }^{1 *}$ Nurhannifah Rizky Tampubolon, ${ }^{2}$ Wahyu Dwi Fatimah, ${ }^{3}$ Arifka Uli Nur Hidayati \\ ${ }^{1}$ Institut Kesehatan Helvetia Medan \\ ${ }^{1,2,3}$ Magister Keperawatan, Fakultas Kedokteran, Kesehatan Masyarakat dan Keperawatan, \\ Universitas Gadjah Mada, Yogyakarta, Indonesia. \\ *Corresponding Author \\ Email: ${ }^{1}$ nurhannifahrizkytampubolon@ helvetia.ac.id; ${ }^{2}$ wahyu.dwi.f94@mail.ugm.ac.id, \\ arifka.uli.n@mail.ugm.ac.id
}

Tanggal Submisi : 08 Desember 2020; Tanggal Penerimaan : 27 Februari 2021

\begin{abstract}
ABSTRAK
Perawatan paliatif di Indonesia masih belum populer dibandingkan dengan perawatan kuratif dan rehabilitatif.WHO secara eksplisit telah menyatakan pentingnya perawatan paliatif sebagai bagian dari pelayanan yang komprehensif pada penyakit tidak menular. Berdasarkan kondisi tersebut, studi ini bertujuan untuk mengidentifikasi hambatanhambatan dalam mengimplementasikan perawatan paliatif di Indonesia. Studi literatur ini dilakukan denganpanduan alur PRISMA, pencarian literatur menggunakan kata kunci "palliative care", "barrier", "problem", "challenge", dan "Indonesia" pada situs pencarian PubMed dan Google Schoolar.Hasil pencarian didapatkan 16 artikel dan yang memenuhi kriteria sebanyak 4 artikel, yaitu full text, research article,publikasi dalam rentang tahun 2010-2019, menggunakan Bahasa Indonesia dan Bahasa Inggris, serta fokus pada hambatan danpelaksanaan perawatan paliatif di Indonesia. Hambatan implementasi perawatan paliatif yaitu persepsi pasien dan pemberi perawatan yang masih kurang, dan belum ada standar nasional tentang perawatan pada pasien paliatif. Peningkatan pemahaman dan keterampilan perawatan paliatif juga perlu diberikan pada keluarga pasien karena perawatan dari keluarga dapat meningkatkan kualitas hiduppasien paliatif.
\end{abstract}

Kata kunci : Hambatan, Implementasi, Perawatan Paliatif

\begin{abstract}
Palliative care in Indonesia is still less popular than curative and rehabilitative treatments, even WHO has explicitly stated that the importance of palliative care as part of a comprehensive service in non-communicable diseases. Based on these condition, this study want to identify the barriers in implementing palliative care in Indonesia. This literature study was conducted with the PRISMA flow guide, literature searches using the keywords "palliative care", "barrier", "problem", "challenge", and "Indonesia" on the PubMed and Google Schoolar search sites.The search results obtained 16 articles
\end{abstract}


and 4 articles that met the criteria. There arefull text article, research articles, publications in the period 2010-2019, used Indonesian and English, and focused on barriers and implementation of palliative care in Indonesia.The barriers of the implementation palliative care are the insufficient perceptions of patients and care providers, and there is no national standard of care for palliative patients. Increased understanding and skills of palliative care also need to be given to the patient's family because care from the family can improve the quality of life of palliative patients.

Keywords: Barrier, Implementation, Palliative Care

ISSN 1979-7621 (Print). ISSN 2620-7761 (Online).

DOI : $10.23917 /$ jk.v14i1.12815

\section{PENDAHULUAN}

Perawatan paliatif di Indonesia masih belum populer dibandingkan dengan perawatan kuratif dan rehabilitatif. Padahal jumlah penderita penyakit yang belum dapat disembuhkan terus meningkat pada populasi dewasa dan anak seperti penyakit kanker, penyakit paru obstruktif, HIV, penyakit degeneratif, gagal jantung dan penyakit lainnya. Di tingkat global, WHO secara eksplisit telah menyatakan bahwa pentingnya perawatan paliatif sebagai bagian dari pelayanan yang komprehensif pada penyakit tidak menular (Non-Communicable Dissease/NCD) (Fadhil et al., 2017).

Hambatan implementasi perawatan paliatif di negara bagian Eropa diidentifikasi karena 2 hal yaitu karakteristik individual dan organisasional (Dy et al., 2017). Kementerian Kesehatan Republik Indonesia telah mengeluarkan Kebijakan Perawatan Paliatif sejak tahun 2007, namun belum ada perkembangan yang signifikan terhadap peningkatan jumlah instansi kesehatan yang menerapkan perawatan paliatif. Selain itu, penelitian terkait perawatan palitiaf di Indonesia masih sangat kecil jumlahnya.

Perawatan paliatif erat kaitannya dengan memberikan dukungan atau persiapan berduka bagi pasien dan keluarga. Namun, dukungan berduka masih merupakan hambatan dalam mengimplementasikan perawatan paliatif di tingkat sistem pelayanan. Tenaga kesehatan khususnya perawat dalam memberikan dukungan berduka tergantung kepada kemampuannya untuk menjalin kontak atau kedekatan dengan pasien yang akan meninggal (Phillips et al., 2018), belum ada panduan terstandar.

Perlu dilakukan analisa mendalam terkait hambatan-hambatan dalam mengimplementasikan perawatan paliatif di Indonesia untuk dapat diatasi, sehingga perawatan paliatif dapat diterapkan di berbagai instansi pelayanan kesehatan. Tujuan studi pustaka ini yaitu untuk mengetahui hambatan-hambatan dalam mengimplementasikan perawatan paliatif di Indonesia.

\section{METODE PENELITIAN}

Penelitian ini bertujuan untuk memberikan pandangan yang komprehensif mengenai hambatan pelaksanaan perawatan paliatif di Indonesia dengan mengulasartikel peer-reviewed. Literature review ini dilakukan mengikuti panduan PRISMA (Pati \& Lorusso, 2018). Strategi pencarian literatur dengan merumuskan masalah studi menggunakan PICO (population, intervention, comparison, outcome).Populasi studi ini adalah pasien paliatif di Indonesia, 
dengan intervensi perawatan paliatif dan luaran berupa hambatan. Kata kunci pencarian literatur terdiri dari Indonesia AND palliative care AND barrier OR problem OR challenge.Database pencarian dilakukan melalui Pubmed dan Google Schoolar.

Kriteria inklusi artikel yang akan direview terdiri dari artikel yang dipublikasi dalam rentang tahun 2010 sampai tahun 2019, peer-reviewed publication, dan dapat diakses full text secara gratis. Pemilihan literatur terbatas hanya pada publikasi yang menggunakan Bahasa Indonesia dan Bahasa Inggris. Fokus pemilihan literatur yaitu pada luaran berupa hambatan dan implementasi perawatan paliatif di Indonesia.
Artikel dieksklusi dengan kriteria nonresearch publicationdan terdapat bias. Dua orang peneliti melakukan critical appraisal menggunakan instrumen dari JBI (Joanna Briggs Institute) untuk penelitian dengan desain kualitatif dan cross-sectional.Setiap literatur yang diskrining, dibaca keseluruhannya untuk melihat relevansinya dengan luaran berupa hambatan dan implementasi perawatan paliatif di Indonesia.Tinjauan literatur ini dianalisis dan dibahas dalam bentuk deskriptif untuk kemudian dikombinasikan denganliterature lain terkait implementasi perawatan paliatif di Indonesia.

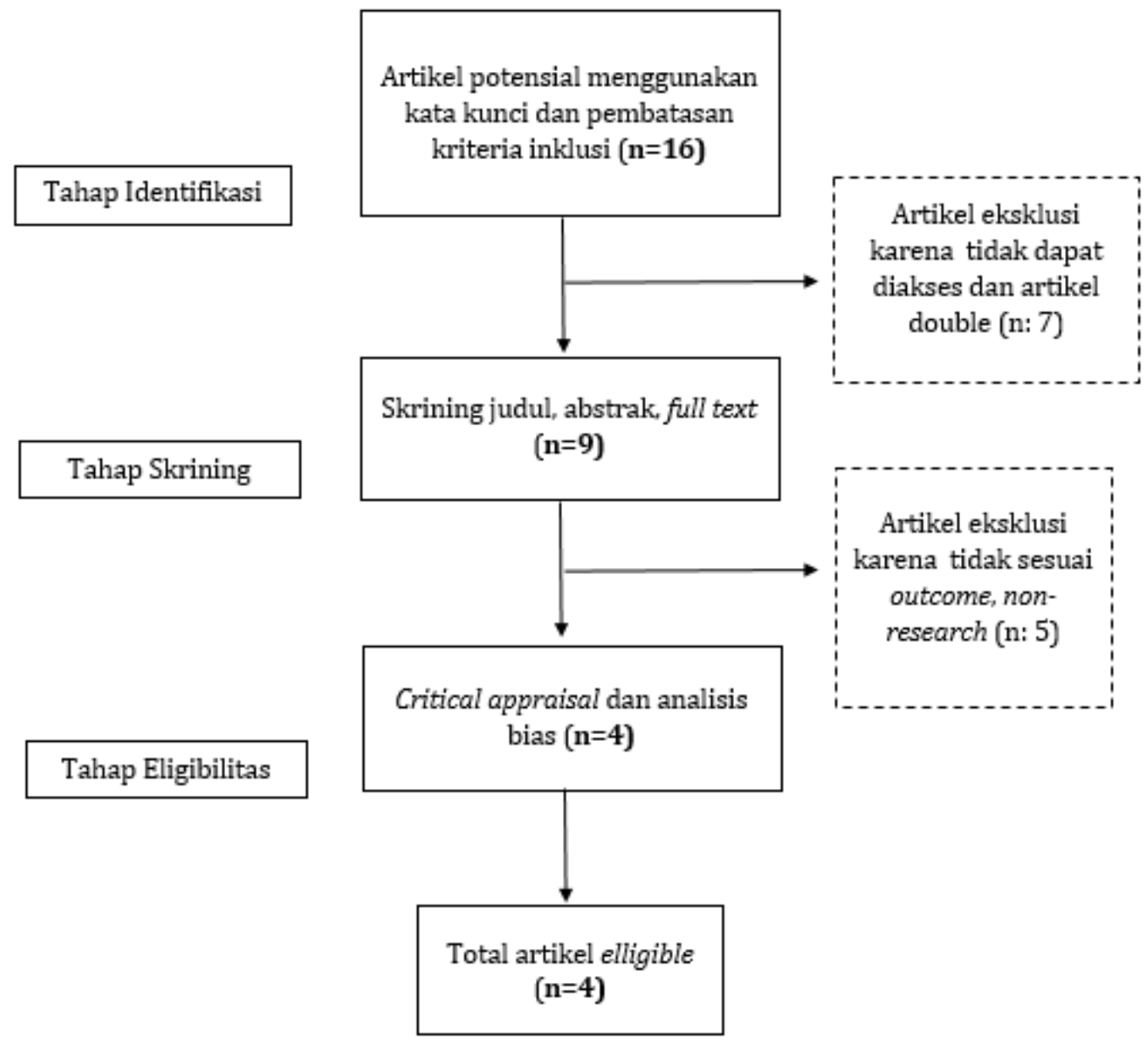

Gambar 1. Alur diagram PRISMA

\section{HASIL DAN PEMBAHASAN}

Hasil pencarian literatur diperoleh 16 artikel hasil identifikasi menggunakan kata kunci dan yang memenuhi kriteria sebanyak 4 artikel. Tiga artikel diperoleh dari Pubmed dan 1 artikel dari Google schoolar. Hasil pencarian literaturditampilkan dalam diagram 
alur PRISMA pada Gambar 1. Ringkasan dan sintesis artikel yang di-review ditampilkan dalam Tabel 1. Hampir semua artikel yang di-reviewmembahas implementasi perawatan paliatif yang belum memenuhi kebutuhan pasien dan keluarga. Terdapat 1 artikel yang membahas secara khusus aspek spiritual/agama dalam implementasi perawatan paliatif.

Tiga artikel memaparkan bagaimana implementasi perawatan paliatif di Indonesia dari sudut pandang pasien dan pemberi layanan. Diperoleh hasil bahwa pasien merasa kurang mendapat perhatian dari pemberi layanan perawatan paliatif sehingga kebutuhan-kebutuhan pasien paliatif belum dapat terpenuhi (Effendy et al., 2014). Kebutuhan utama yang belum terpenuhi yaitu dukungan psikologis dan informasi yang lengkap terkait kondisi kesehatan pasien paliatif yang sudah menjelang ajal (Nova, 2018). Hal ini terjadi karena kurangnya pengetahuan dan keterampilan terkait perawatan paliatif (Nova, 2018) dan tidak terdapat standar panduan pelayanan paliatif (Arisanti et al., 2019).

Kebutuhan spiritual meningkat pada pasien paliatif sehingga keluarga menyediakan sendiri peralatan yang dibutuhkan seperti kitab suci atau perlengkapan ibadah (Rochmawati et al., 2018). Pada layanan perawatan paliatif yang diberikan oleh organisasi non-profit, aspek spiritual saling mendukung antara pasien, keluarga, dan tim paliatif. Selain itu, tim paliatif menjalankan praktik dengan nilainilai religius dan melakukan ibadah bersama dengan pasien dan keluarga. Terdapat toleransi beragama dalam praktik perawatan oleh tim paliatif, karena terdapat perbedaan agama dan waktu beribadah. Hal ini tidak sejalan dengan implementasi perawatan paliatif pada umumnya, tetapi artikel ini dapat menjadi rekomendasi untuk implementasi perawatan palitif ke depannya.

Hambatan dalam implementasi perawatan paliatif dijabarkan dalam tiga garis besar yaitu miskonsepsi perawatan paliatif, integrasi aspek spiritual dalam praktik perawatan paliatif, dan kebutuhan standar perawatan paliatif. Penjabaran hasil hambatan implementasi perawatan paliatif lebih lanjut dibahasdengan integrasi literatur lain yang terkait.

\section{Miskonsepsi perawatan paliatif}

Pemberi perawatan kesehatan profesional menganggap bahwa masalah psikologis, kesulitan sosial dan aspek spiritual bukan merupakan perawatan yang harus diberikan pada pasien paliatif(Witjaksono et al., 2014). Keinginan profesional kesehatan untuk memberikan perawatan sampai akhir di rumah sakit, menjadi landasan penolakan untuk merujuk pasien pada perawatan paliatif sehingga tabu untuk membahas tentang kematian, menghindari penggunaan opioid, takut kehilangan kontrol dan penghasilan (Witjaksono et al., 2014).Keinginan tersebut juga berlaku pada masyarakat atau keluarga pasien sehingga perawatan paliatif menjadi sulit untuk diterapkan terutama dalam memberikan perawatan pada akhir kehidupan, karena membahas kematian masih dianggap tabu.

Kepercayaan pasien dan keluarga terhadappenyakit dan ketergantungan perawatan di rumah sakit dipicu karena rendahnya pengetahuan dan keterampilan dalam memberikan perawatan paliatif (Iskandarsyah et al., 2014).Banyak keluarga yang menempatkan pasien tetap di rumah sakit karena ketidakadekuatan keterampilan anggota keluargadalam proses perawatan paliatif pasien di rumah. Padahal pasien mengalami peningkatan kualitas hidup ketika dirawat di rumah bersama dengan keluarga(Kristanti et al., 2017). Perlu diberikan pelatihan keterampilan yang meliputi memandikan, mencuci rambut, membantu eliminasi, perawatan mulut dan memberikan makan di tempat tidur sehingga keluarga dapat memberikan yang terbaik pada akhir kehidupan pasien paliatif.

Kesadaran pasien atau persepsi pasien merupakan salah satu faktor utama dalam penerapan perawatan paliatif yang ada di dunia, tidak hanya itu, persepsi pemberi pelayanan kesehatan pun turut menentukan hasil dari perawatan paliatif(Sommerbakk et al., 2016). Pola komunikasi paternalistik antara pasien dan pemberi layanan kesehatan 
menyebabkan

dibutuhkanpasien dan keluarga tidak didapatkan.Pasien merasa inferior karena latar belakang pasien/keluarga terkait rendahnya pendidikan atau berasal dari perkampungan, dan berharap semua keputusan diarahkan oleh dokter, pasien lebih memilih untuk menghindari konsultasi yang dianggap akan menimbulkan konflik (Iskandarsyah et al., 2014).

Pasien dan keluarga membutuhkan informasi yang lebih detail untuk mengatasi kondisi ketidakpastian, tetapi informasi tersebut tidak didapatkan karena profesional kesehatan mengalami kesulitan untuk menyampaikan kabar buruk (Nova, 2018). Hal ini menunjukkan bahwa persepsi pasien dan pemberi perawatan yang masih kurang sehingga perawatan paliatif yang diberikan belum mampu memenuhi kebutuhan pasien dan keluarga pasien.

\section{Integrasiaspek spiritualdalam praktik perawatan paliatif}

Masyarakat Indonesia memandang agama sebagai kebutuhan yang sangat penting dalam sepanjang kehidupan dan akan meningkat ketika seorang individu mengidap suatu penyakit. Pemahaman terhadap religiusitas dan praktik spiritual merupakan elemen yang integral dengan budaya dan menjadi dasar penting yang dibutuhkan dalam memberikan pelayanan kesehatan yang holistik (Rochmawati et al., 2018).

Tenaga kesehatan perlu memperhatikan aspek spiritual pada pasien paliatif, salah satu dukungan yang dapat diberikanya itu dengan menghadirkan pembimbing rohani. Tenaga kesehatan juga perlu memahami bahwa pasien akan merasa lebih nyaman, apabila selama menjalani perawatan paliatif mereka ditempatkan di ruangan yang khusus untuk perawatan paliatif (Enggune et al., 2014).

Profesional kesehatan dalam perawatan paliatif dengan prespektif dan praktik spiritual yang kuat berdampak dalam pemenuhan kebutuhan spiritual pasien karena akan membantu memfasilitasi atau dapat berperan sebagai konselor spiritual (Rochmawati et al., 2018). Namun, apabila profesional kesehatan tidak memiliki nilai spiritual yang cukup, akan menjadi hambatan dalam perawatan paliatif karena profesional tersebut akan mengalami kesulitan dalam memfasilitasi kebutuhan spiritual pasien.

\section{Kebutuhan standar perawatan paliatif}

Effendy et al.(2014)menyatakan bahwa pasien paliatif di Indonesia memiliki permasalahan fisik, permasalahan finansial, permasalahan psikologis dan otonomi serta menyampaikan bahwa kebutuhan yang tidak terpenuhi pada pasien-pasien paliatif di Indonesia lebih banyak dari pada pasienpasien paliatif di Belanda. Pasien paliatif di Indonesia menyampaikan bahwa kebutuhan terkait masalah-masalah yang mereka alami pada masa paliatif tidak terpenuhipada banyak aspek. Hal ini terjadi karena sedikitnya fasilitas untuk melakukan perawatan, belum ada standar nasional tentang perawatan pada pasien paliatif, dan kurangnya pelatihan kepada perawat terkait perawatan paliatif (Effendy et al., 2014).

Tidak adanya modul perawatan paliatif dalam kurikulum medis menyebabkan hanya sedikit dokter bersertifikat dalam perawatan paliatif. Dokter ahli paliatif yang ada saat ini hanya berbasis pada dua kota yaitu Surabaya dan Jakarta (Witjaksono et al., 2014). Pendidikan tentang perawatan paliatif kepada perawat juga masih kurang. Hal ini menyebabkan kurangnya pengetahuan perawat tentang perawatan paliatif. Gambaran pengetahuan perawat tentang paliatif pada bangsal atau unit penyakit terminal sebagian besar dalam kategori cukup (Giarti, 2018; Sulaeman, 2016).

Pengetahuan perawat tentang perawatan paliatif berhubungan dengan sikap perawat terhadap penatalaksanaan pasien dalam perawatan paliatif. Semakin baik pengetahuan perawat tentang perawatan paliatif, maka semakin baik pula sikap perawat terhadap penalataksanaan pasien dalam perawatan paliatif (Wulandari, 2015). Hal serupa juga disampaikan oleh Nurmasari (2013) yang menjelaskan bahwa efektifitas tim ICU dalam memberikan perawatan paliatif masih buruk. Kondisi ini terjadi karena kurangnya pengetahuan tentang 
perawatan paliatif sehingga tim ICU tidak mengetahui secara pasti bagaimana perawatan paliatif yang ideal di ICU.

Hambatan-hambatan implementasi perawatan paliatif dari segi profesional kesehatan dapat ditangani dengan menyusun standar nasional tentang perawatan pada pasien paliatif (Effendy et al., 2014), termasuk pada kurikulum pendidikan (Witjaksono et al., 2014). Engguneet al.(2014)juga menyampaikan bahwa perlu adanya perbaikan dalam perawatan paliatif yaitu dengan melakukan pelatihan terkait perawatan paliatif, khususnya dalam menyampaikan berita buruk dan perawatan menjelang ajal. Penelitian lain menyebutkan bahwa perlu perhatian untuk meningkatkan akses, fasilitas, dan layanan kesehatan dalam mengimplementasikan perawatan paliatif (Arisanti et al., 2019).

Tabel 1. Ringkasan dan Sintesis Hasil Studi

\begin{tabular}{|c|c|c|c|}
\hline Peneliti/Tahun & Tujuan & Metode & Sintesis \\
\hline $\begin{array}{l}\text { Arisanti et al. } \\
\text { (2019) }\end{array}$ & $\begin{array}{l}\text { Untuk } \\
\text { mengeksplorasi } \\
\text { bagaimana status } \\
\text { layanan dan } \\
\text { ekspektasi } \\
\text { perawatan paliatif } \\
\text { di Indonesia dari } \\
\text { perspektif tenaga } \\
\text { kesehatan }\end{array}$ & $\begin{array}{l}\text { Kualitatif dengan } \\
\text { pendekatan studi kasus } \\
\text { Pengumpulan data } \\
\text { dilakukan dengan in- } \\
\text { depth interview } \\
\text { Partisipan terdiri dari } 12 \\
\text { dokter dan } 5 \text { perawat, } \\
\text { berasal dari } 9 \\
\text { puskesmas dan } 2 \text { rumah } \\
\text { sakit di Bandung } \\
\text { dengan prevalensi } \\
\text { penyakit kronis yang } \\
\text { tinggi }\end{array}$ & $\begin{array}{l}\text { Dibutuhkan panduan } \\
\text { standar layanan } \\
\text { perawatan paliatif untuk } \\
\text { meningkatkan layanan } \\
\text { perawatan paliatif. } \\
\text { Diharapkan ada } \\
\text { kebijakan untuk } \\
\text { mengimplementasikan } \\
\text { panduan standar } \\
\text { tersebut pada semua } \\
\text { tingkat sehingga } \\
\text { terbentuk kolaborasi } \\
\text { interdisiplin dalam } \\
\text { memberi perawatan } \\
\text { paliatif. }\end{array}$ \\
\hline $\begin{array}{l}\text { Effendy et al. } \\
\text { (2014) }\end{array}$ & $\begin{array}{l}\text { Untuk menentukan } \\
\text { apakah pasien } \\
\text { dengan penyakit } \\
\text { kanker lanjut di } \\
\text { Indonesia } \\
\text { memiliki masalah } \\
\text { dan kebutuhan } \\
\text { yang tidak } \\
\text { terpenuhi seperti } \\
\text { pasien di Belanda }\end{array}$ & $\begin{array}{l}\text { Desain cross-sectional } \\
\text { survey } \\
\text { Pengumpulan data } \\
\text { menggunakan kuesioner } \\
\text { Problem and needs in } \\
\text { palliative care-short } \\
\text { version } \\
\text { Sampel merupakan } \\
\text { pasien paliatif: } \\
\text { - } 180 \text { warga Indonesia } \\
\text { - } 94 \text { warga Belanda } \\
\end{array}$ & $\begin{array}{l}\text { Pasien Indonesia kurang } \\
\text { diberikan perhatian dari } \\
\text { profesional kesehatan } \\
\text { pada hampir semua } \\
\text { masalah yang muncul } \\
\text { dalam perawatan } \\
\text { paliatif sehingga banyak } \\
\text { kebutuhan yang tidak } \\
\text { terpenuhi. }\end{array}$ \\
\hline Nova (2018) & $\begin{array}{l}\text { Untuk } \\
\text { menginvestigasi } \\
\text { bagaimana } \\
\text { persepsi pasien } \\
\text { dengan penyakit } \\
\text { jantung kronis } \\
\text { mendapatkan } \\
\text { pelayanan paliatif } \\
\text { sesuai dengan } \\
\text { yang dibutuhkan }\end{array}$ & $\begin{array}{l}\text { Penelitian kualitatif di } \\
\text { salah satu rumah sakit } \\
\text { di Indonesia } \\
\text { Pengumpulan data } \\
\text { dilakukan dengan semi- } \\
\text { structured interviews } \\
\text { Partisipan (n=5) } \\
\text { merupakan pasien rawat } \\
\text { inap yang memiliki } \\
\text { penyakit jantung kronis } \\
\text { dan telah menjalani } \\
\text { perawatan di RS }\end{array}$ & $\begin{array}{l}\text { Dukungan psikologis } \\
\text { dibutuhkan karena } \\
\text { ketidakpastian } \\
\text { pengobatan yang kurang } \\
\text { didapatkan dari tenaga } \\
\text { kesehatan } \\
\text { Perawatan menjelang } \\
\text { ajal menjadi bagian } \\
\text { terakhir dalam } \\
\text { pelayanan paliatif, } \\
\text { Pasien membutuhkan } \\
\text { informasi yang lengkap } \\
\text { tentang penyakitnya, }\end{array}$ \\
\hline
\end{tabular}




\begin{tabular}{|c|c|c|c|}
\hline Peneliti/Tahun & Tujuan & Metode & Sintesis \\
\hline & & & $\begin{array}{l}\text { sementara tenaga } \\
\text { kesehatan kesulitan } \\
\text { dalam menyampaikan } \\
\text { informasi terkait } \\
\text { perawatan menjelang } \\
\text { ajal }\end{array}$ \\
\hline $\begin{array}{l}\text { Rochmawati et } \\
\text { al. (2017) }\end{array}$ & $\begin{array}{l}\text { Untuk } \\
\text { mendapatkan } \\
\text { pemahaman terkait } \\
\text { aspek } \\
\text { spiritual/religius } \\
\text { pada praktek } \\
\text { perawatan paliatif } \\
\text { di Indonesia yang } \\
\text { dibutuhkan pasien } \\
\text { dan keluarga }\end{array}$ & $\begin{array}{l}\text { Kualitatif etnografi di } 2 \\
\text { unit layanan paliatif } \\
\text { yaitu rumah sakit dan } \\
\text { organisasi non-profit } \\
\text { Pengumpulan data: } \\
\text { Observasi lapangan, } \\
\text { kuisioner, diskusi } \\
\text { informal, wawancara } \\
\text { dan telaah dokumen } \\
\text { Partisipan (n=48): } \\
\text { - Tenaga kesehatan } \\
\quad \text { profesional } \\
\quad \text { pemberi layanan } \\
\quad \text { paliatif } \\
\text { - Pasien paliatif } \\
\text { - Keluarga pasien } \\
\quad \text { paliatif }\end{array}$ & $\begin{array}{l}\text { Aspek spiritual/agama } \\
\text { dalam layanan paliatif } \\
\text { tidak hanya diberikan } \\
\text { sebagai bentuk } \\
\text { dukungan untuk pasien } \\
\text { dan keluarga tetapi juga } \\
\text { bagian dalam } \\
\text { menjalankan praktik. } \\
\text { Aspek spiritual sebagai } \\
\text { suatu kebutuhan yang } \\
\text { tidak hanya dipenuhi } \\
\text { oleh tim paliatif kepada } \\
\text { pasien dan keluarga, } \\
\text { tetapi berlaku juga } \\
\text { sebaliknya. }\end{array}$ \\
\hline
\end{tabular}

\section{KESIMPULAN}

Hambatan yang muncul di Indonesia dalam perawatan paliatif yaitu persepsi pasien dan pemberi perawatan yang masih kurang dan belum ada standar nasional tentang perawatan pada pasien paliatif. Peningkatan pemahaman dan keterampilan perawatan paliatif juga perlu diberikan pada keluarga pasien, karenaperawatan paliatif yang diberikan keluarga dapat meningkatkan kualitas hiduppasien paliatif. Pasien paliatif di Indonesia mengalami peningkatan kebutuhan spiritual, sehingga dibutuhkan profesional kesehatan yang memiliki nilai religius dan menerapkan aspek spiritual dalam memberikan perawatan paliatif.

\section{UCAPAN TERIMAKASIH}

Ucapan terimakasih diberikan kepada pembimbing mata kuliah keperawatan paliatif, program studi magister keperawatan, Universitas Gadjah Mada. Bimbingan yang diberikan menghasilkan karya tulis publikasi yang dapat dijadikan bahan referensi bagi layanan perawatan paliatif.

\section{DAFTAR PUSTAKA}

Arisanti, N., Pudji, E., Sasongko, S., Pandia, V., \& Hilmanto, D. (2019). Implementation of palliative care for patients with terminal diseases from the viewpoint of healthcare personnel. BMC Research Notes, 3-7. https://doi.org/10.1186/s13104-019-4260-x

Dy, S. M., L-Hamayel, N. A., \& Hannum, Susan M., Sharma, Ritu., Isenberg, Sarina R., Kuchinad, Kamini., et al. (2017). A survey to evaluate faciilitators and barriers to quality measurement and improvement: adapting tools for implementation research in palliative care programs. Journal of Pain and Symptom Management, Vol.54(6).

Effendy, C., Vissers, K., Osse, B. H. P., Tejawinata, S., Vernooij-Dassen, M., \& Engels, Y. (2014). Comparison of Problems and Unmet Needs of Patients with Advanced 
Cancer in a European Country and an Asian Country. World Institute of Pain, 15(5), 433-440.

Enggune, M., Ibrahim, K., \& Rizmadewi Agustina, H. (2014). Persepsi Perawat Neurosurgical Critical Care Unitterhadap Perawatan Pasien Menjelang Ajal. Jurnal Keperawatan Padjadjaran, v2(n1), 35-42. https://doi.org/10.24198/jkp.v2n1.5

Fadhil, I., Lyons, G., \& Payne, S. (2017). Barriers to, and Oppportunities for, Palliative Care Development in the Eastern Mediterania Region. Lancet Oncol, 18e, 176184.

Giarti, A. T. (2018). Gambaran Pengetahuan Perawat tentang Perawatan Paliatif pada Pasien Kanker di RSUD dr. Moewardi. Universitas Muhammadiyah Surakarta.

Iskandarsyah, A., de Klerk, C., Suardi, D. R., Soemitro, M. P., Sadarjoen, S. S., \& Passchier, J. (2014). Psychosocial and cultural reasons for delay in seeking help and nonadherence to treatment in Indonesian women with breast cancer: A qualitative study. Health Psychology, 33(3), 214-221. https://doi.org/10.1037/a0031060

Kristanti, M. S., Setiyarini, S., \& Effendy, C. (2017). Enhancing the quality of life for palliative care cancer patients in Indonesia through family caregivers: A pilot study of basic skills training. BMC Palliative Care, 16(1), 1-7. https://doi.org/10.1186/s12904-016-0178-4

Nova, P. A. (2018). Chronic heart failure patients' perceptions on their palliative care needs. Enfermería Clínica, 28.

Nurmasari, P. (2013). Efektivitas Tim Intensive Care Unit dalam Pemberian Perawatan Paliatif di RSUP dr. Sardjito Yogyakarta. Universitas Gadjah Mada.

Pati, D., \& Lorusso, L. N. (2018). How to Write a Systematic Review of the Literature. Health Environments Research and Design Journal, 11(1), 15-30. https://doi.org/10.1177/1937586717747384

Phillips, J. L., Lobb, E., Mohacs, P., Heneka, N., \& Currrow, D. (2018). Identifying Systems Barriers that May Prevent Bereavement Service Access to Bereaved Cares:a Report from an Australian Specialist Palliative Care Service. Collegian, $25,39-43$.

Rochmawati, E., Wiechula, R., \& Cameron, K. (2018). Centrality of spirituality/religion in the culture of palliative care service in Indonesia: An ethnographic study. Nursing \& Health Sciences, June 2017, 1-7. https://doi.org/10.1111/nhs.12407

Sommerbakk, R., Haugen, D. F., Tjora, A., Kaasa, S., \& Hjermstad, M. J. (2016). Barriers to and facilitators for implementing quality improvements in palliative care - Results from a qualitative interview study in Norway. BMC Palliative Care, 15(1), 1-17. https://doi.org/10.1186/s12904-016-0132-5

Sulaeman, A. S. (2016). Gambaran Pengetahuan Perawat tentang Perawatan Paliatif pada Pasien dengan Kondisi Terminal di RSUD Kabupaten Bekasi. Universitas Negeri Syarif Hidayatullah.

Witjaksono, M. A., Sutandiyo, N., \& Suardi, D. (2014). Regional support for palliative care in Indonesia: The Challenges to Developing Palliative Care in Indonesia and the Value of Support from other Organisations in the Asia Pacific Region. Ehospice.

Wulandari, F. (2015). Hubungan Tingkat Pengetahuan Perawat tentang Perawatan Paliatif dengan Sikap terhadap Penatalaksanaan Pasien dalam Perawatan Paliatif di RS DR. Moewardi Surakarta. Naskah Publikasi, 1-19. 
N.R Tampubolon, D.W Fatimah \& A.U.N Hidayati / Jurnal Kesehatan 14 (1) 2021, 1-10 